\title{
MODIFIED COM POSITES BASED ON POLY(ETHYLENE-VINYL ACETATE) AND CRUMB RUBBER
}

\author{
Volodymyr M yshak ${ }^{1,}$, Vita Seminog ${ }^{1}$, Volodymyr Grishchenko ${ }^{1}$, \\ Antonina Barantsova ${ }^{1}$
}

https://doi.org/10.23939/chcht11.04.454

\begin{abstract}
The blocked macrodiisocyanates (MDI) based on oligodienes with hydroxyl groups and a blocking agent $p$-quinonedioxyme have been synthesized. The effect of the modifier (blocked MDI) on the physical mechanical characteristics and structural features of composites based on the dispersed crumb rubber and functionalized poly(ethylene-vinyl acetate) were investigated. The effective concentration of the blocked MDI and its influence on mechanical and deformation characteristics of composites were studied. It is shown that blocked MDI acts as a modifier in prepared composites and leads to improving of mechanical properties.
\end{abstract}

Keywords: crumb rubber, poly(ethylene-vinyl acetate), the blocked macrodiisocyanate, composites, modification.

\section{Introduction}

The properties of composite polymer materials depend on the interaction of components on the interphase, for example, polyethylene and rubber, copolymer of ethylene-vinyl acetate and rubber, etc. Adhesion depends on the affinity of the components, their compatibility, that is determined by the chemical structure the presence of functional and reactive groups. To strengthen the interaction between components, their structural modification (functionalization) has been performed. The functional groups capable to participate in the formation of intermolecular bonds were introduced to the polymer chains. The reduction of the surface tension of interphase adhesion is explained by the formation of the network of intermolecular physical bonds. The efficiency of modification depends on the type and content of functional groups in the polymer components. A significant role is played by modifiers, which act as plasticizers, compatibilizers and can form additional chemical or physical bonds between functional groups of

\footnotetext{
${ }^{1}$ Institute of Macromolecular Chemistry NAS of Ukraine,

48, Kharkivske Hwy., 02160 Kyiv, Ukraine

*vmyshak@ihvs.nas.gov.ua

(C) Myshak V., Seminog V., Grishchenko V., Barantsova A., 2017
}

components in composites. The blocked MDI are advanced materials for modification of rubber plastics. They are resistant to moisture and react only at high temperatures, after unlocking of isocyanate groups [1-8].

Based on the above-mentioned, the aim of this work was to study prospects of creation of rubber plastics based on dispersed rubber crumb, poly(ethylene-vinyl acetate), functionalized on the surface of the granules, and the modifier based on the liquid rubber with functional groups. The investigations of structural features and physical mechanical characteristics of the created compositions were performed.

\section{Experimental}

For research and the creation of composites, as a filler a crumb rubber (CR) obtained by grinding of depreciated tires and functionalized poly(ethylene-vinyl acetate) (PEVA) with content of vinyl acetate groups $33 \%$ (product of "Atofina", France) were used. The functionalization of thermoplastics was carried out by alkaline alcoholysis reaction. For this purpose the solution of $\mathrm{KOH}$ in ethanol was taken in excess $(5 \%)$ relatively to the acetate groups. The reaction was performed on the surface of the granules of the polymer at temperatures of 298 and $343 \mathrm{~K}$ for $26.5 \mathrm{~h}$. The obtained copolymer was poured to the diethyl ether and dried under vacuum at $323 \mathrm{~K}[9,10]$.

The availability of studied hydroxyl $(\mathrm{OH})$ groups on the surface of the granules PEVA and structural features of their location were determined by FTIR spectroscopy. The kinetics of the reactions of alcoholysis was studied by FTIR spectroscopy on the surface of the PEVA granules. During certain period of time samples were scanned. The intensity of the broad bands in the region of 3300-3500 $\mathrm{cm}^{-1}$ with a maximum of $3450 \mathrm{~cm}^{-1}$ are related to the stretching vibrations of formed $\mathrm{OH}-$ groups. The band $2947 \mathrm{~cm}^{-1}$ in the spectrum of the initial polymer, which is responsible for stretching vibrations of $\mathrm{CH}$-groups was adopted as a internal standard. For each point of measurements the ratio of the intensity of a 
standard of $\mathrm{CH}$-groups and intensity of the maximum of OH-groups was calculated, and the percentage of formation of $\mathrm{OH}$-groups has determined by mathematical processing of these results, which is further used to plot a kinetic curve of the formation of $\mathrm{OH}$-groups from the time of the reaction.

The content of hydroxyl groups in PEVA after the reaction of alcoholysis was determined analytically by acetylation according to standard procedures.

Blocked MDI based on oligodienediol produced by "Krasol LBH-3000" was used as a modifier in proposed composites. Composite materials based on $50 \%$ of functionalized PEVA 3345, 50 \% CR and a modifier was prepared by mechanically mixing of the components with subsequent homogenisation of the obtained mixture in the extruder, under appropriate strain and temperature conditions, with the introduction of various amounts of blocked macrodiisocyanate. The content of modifying additives was $3,7,15,20 \mathrm{wt} \%$.

For obtaining of modified rubber plastics, $15 \%$ solution of functionalized PEVA 3345 in distilled and dried toluene was prepared, firstly. The resulting solution was mixed with CR. To achieve homogeneity, the mixture was thoroughly stirred in a mixer at room temperature for $0.5 \mathrm{~h}$ and then dried until reaching a constant weight and extruded at $373 \mathrm{~K}$. The resulting extrudate was ground and added a blocked MDI in the above proportions and extruded at a temperature of $373 \mathrm{~K}$ below the temperature of unblocking blocked MDI (393 K).

The samples for physical mechanical studies in the form of bilateral shoulder blades were obtained by the method of direct pressing to extrudate compositions, at the temperature of extrusion $433 \mathrm{~K}$, which is above the temperature of the unblocking MDI, the pressing pressure of $5 \mathrm{MPa}$, holding time $5 \mathrm{~min}$ per $1 \mathrm{~mm}$ thickness, followed by cooling under pressure to room temperature (298 K).

Criteria for the evaluation of physico-mechanical properties were adopted: the tensile strength $\left(\sigma_{p}\right)$ and elongation at break $(\Delta \varepsilon)$. Indexes of physico-mechanical properties, $\sigma_{p}$ and $\Delta \varepsilon$, were determined on a tensile testing machine. Stretching of the blades is carried out at a speed of the movable clamp upper traverse $20 \mathrm{~mm} / \mathrm{min}$. Determined limit values $\sigma_{p}$ and $\Delta \varepsilon$, and their average values were calculated over the five samples.

Structural features, kinetics of the fusion reaction process and the chemical structure of materials studied by FTIR spectroscopy (FTIR-spectrometer TENSOR-38, company BRUKER, Germany).

\section{Results and Discussion}

The structure and mechanical properties for composites based on a poly(ethylene-vinyl acetate) and crumb rubber were obtained. The samples of polymer composites and their physical-mechanical properties $\left(\sigma_{p}\right.$, $\Delta \varepsilon)$ are given in Table 1.

The increase of CR concentration up to $50 \mathrm{wt} \%$ in PEVA matrix provides the increase of $\sigma_{p}$. It was shown that these values are greater than the same for initial PEVA by $27 \%$. Obviously, a high content of vinyl acetate groups $(33 \%)$ provides high adhesion between rubber particles at the boundaries of phases and the occurrence of specific interactions between them and functional groups on the surface of the crumbs. The results of spectral investigations confirm this fact (Fig.1).

Addition of $40 \%$ CR (Fig. 1, curve 2) to PEVA leads to the disappearance of bands of stretching vibrations of associated NH-groups at $3302 \mathrm{~cm}^{-1}$, deformation vibrations of $\mathrm{NH}$-groups at $1565 \mathrm{~cm}^{-1}$, the decreasing of intensity of the band of $\mathrm{NH}$-groups deformation vibrations at $1645 \mathrm{~cm}^{-1}$ that may indicate the occurrence of reactions between $\mathrm{NH}$-groups of $\mathrm{CR}$ and functional groups of PEVA.

Alkaline alcoholysis of PEVA was carried out for obtaining functionalized copolymer for further preparation of filled CR composites. The alcoholysis reaction leads to the substitution of part of acetate groups by hydroxyl groups. The reaction scheme is shown below.

The synthesis was investigated by FTIR spectroscopy (Fig. 2).

Table 1

\section{Structure and deformation - strength properties of polymer composites based on PEVA and CR}

\begin{tabular}{|c|c|c|c|}
\hline \multicolumn{2}{|c|}{ The composition of the polymer composites, wt \% } & \multicolumn{2}{|c|}{ Properties of rubber plastics } \\
\hline PEVA 3345 & CR & $\sigma_{p}, \mathrm{MPa}$ & $\Delta \varepsilon, \%$ \\
\hline 100 & 0 & 2.24 & 833.3 \\
\hline 60 & 40 & 2.5 & 278.0 \\
\hline 50 & 50 & 2.8 & 278.3 \\
\hline 40 & 60 & 2.1 & 207.3 \\
\hline 30 & 70 & 1.2 & 88.8 \\
\hline 20 & 80 & 1.74 & 41.2 \\
\hline
\end{tabular}




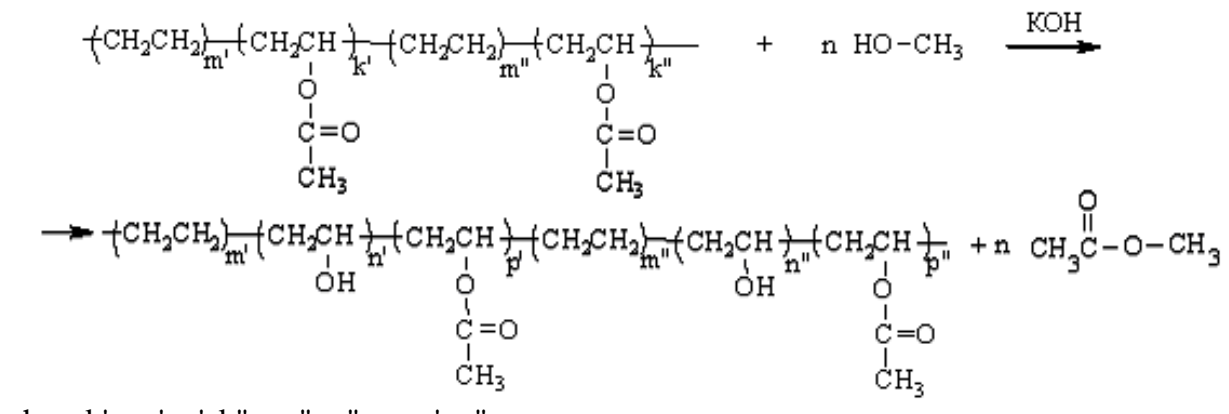

where $k^{\prime}=n^{\prime}+p^{\prime}, k^{\prime \prime}=n^{\prime \prime}+p^{\prime \prime} n=n^{\prime}+n^{\prime \prime}$.

\section{Scheme 1}

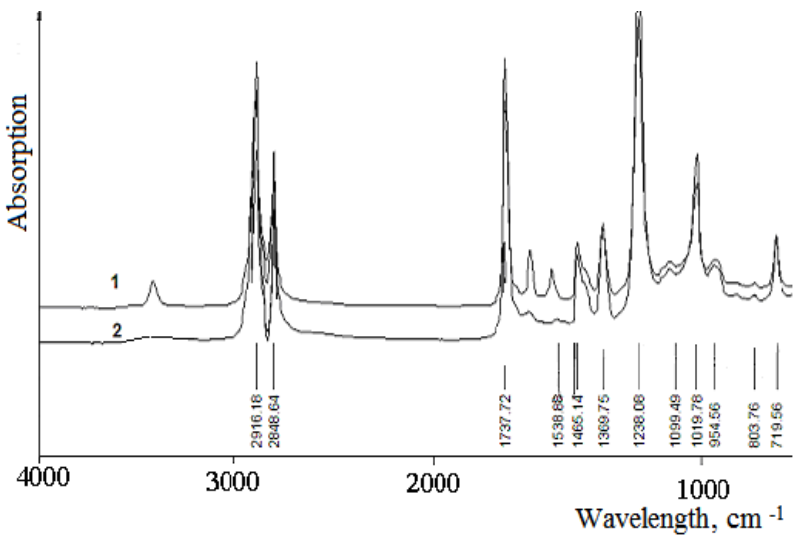

Fig. 1. FTIR spectra of PEVA 3345 (1) and $60 \% \mathrm{CR}+40 \%$ PEVA 3345 (2) composite

To determine the optimal alcoholysis conditions (reaction time, temperature, degree of conversion, etc.) the functionalization of PEVA was carried out at different temperatures: 298 and $343 \mathrm{~K}$. The results of PEVA acetylation and FTIR spectroscopy pointed that increasing the synthesis temperature from 298 to $343 \mathrm{~K}$ promotes the alcoholysis, and leads to the increase of $\mathrm{OH}$ groups content in the copolymer as evidenced by the appearance of new broad bands in the region of $3300-3500 \mathrm{~cm}^{-1}$ and by the decrease in the intensity of stretching vibrations of $\mathrm{C}-\mathrm{O}$ and $\mathrm{C}=\mathrm{O}$ groups in VA copolymer ester group in the area of 1237 and $1736 \mathrm{~cm}^{-1}$, respectively.

At the study of the influence of the introduced hydroxyl groups on the physico-mechanical characteristics of the copolymers, it was found that the structural changes incurred in the process alcoholysis of the original copolymer, tensile strength significantly increases up to $367 \%$ and elongation up to $215 \%$. It can be associated with structuring and reduction of defects of the polymer, increasing it density and with the formation of the hydrogen bonds of hydroxyl groups formed during alcoholysis between the chains of macromolecules of copolymers.

Liquid hydrocarbon rubbers, which are linear oligomeric products based on dienes are perspective

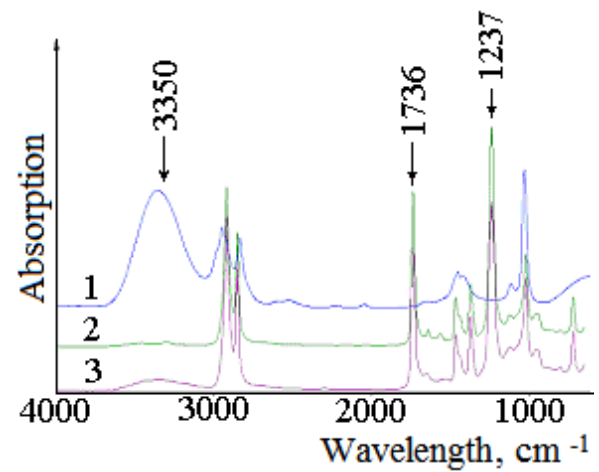

Fig. 2. FTIR spectra of methanol (1), individual PEVA (2) and PEVA with hydroxyl groups (3)

products for use as compatibilizators for rubber-plastic composites. Their advantages depend on a number of properties, primarily their hydrocarbon nature, which promote compatibility with the rubber component of the compositions and, accordingly, improve the adhesion to the rubber [11], and secondly, they are characterized by low viscosity and liquid consistency, are easily distributed on the surface phase, and facilitate blending of all components of the mixture.

For modification of rubber plastics, the blocked MDI was used. It was synthesized from low-molecular diene rubber "Krasol LBH-3000". The synthesis of blocked MDI was carried out in two stages. At the first stage MDI based on the oligodienediol was obtained, which contains hydroxyl groups, interacting with a 2,4tolyendiisocyanate (TDI). The reaction was stopped when the decrease of isocyanate (NCO) groups was $50 \%$, which was determined by the method of FTIR spectroscopy by the decrease of NCO-groups intensity.

At the second stage the obtained macroisocyanate was mixed with $p$-quinonedioxyme ( $p$-QDO), at the equivalent ratio of hydroxyl and isocyanate groups at $353 \mathrm{~K}$. The reaction was considered to be complete when all NCO-groups had reacted. 
The scheme of the synthesis of blocked MDI-based oligodieneurethanediisocyanate with $p$-QDO [12] is given below.

Kinetic relationships of oligodieneurethanediisocyanate and $\mathrm{p}-\mathrm{QDO}$ interaction were investigated by FTIR-spectroscopy. Comparing the spectra of $p$-QDO, MDI and product of their interaction (Fig. 3) we observe the disappearance of the absorption bands of NCO-groups $\left(2274 \mathrm{~cm}^{-1}\right)$, the appearance of the bands of stretching vibrations of $\mathrm{NH}\left(3368 \mathrm{~cm}^{-1}\right)$ and $\mathrm{C}=\mathrm{O}\left(1763 \mathrm{~cm}^{-1}\right)$ of urethane groups, the redistribution of intensity of deformation vibrations of $\mathrm{NH}$ groups in the region of $1500-1531 \mathrm{~cm}^{-1}$, the decrease in the absorption intensity of $\mathrm{C}=\mathrm{N}-\left(1611 \mathrm{~cm}^{-1}\right)$, indicating the formation of the reaction product - oligodieneurethanedioxyme [13].

At $393 \mathrm{~K}$ the process of oligodieneurethanedioxyme unblocking occurs, as a result MDI and $p$-QDO are produced.

The prepared blocked MDI was used as modifying additives in the synthesis of composites based on EVA with hydroxyl groups and CR. It was applied directly to the extrudate compositions and their subsequent homogenization. Thus obtained homogenized compositions were used to prepare the samples for physical and mechanical tests. The resulting decomposition products of the blocked MDI further react with functional groups which are present in CR and hydroxyl groups of PEVA, resulting in formation of additional chemical bonds. Possible scheme of the reaction between MDI, functionalized PEVA and CR are given below (Scheme 3).

In the process of the composites formation ( $433 \mathrm{~K}$ ) unblocking of oligodieneurethanedioxyme occurs with formation of MDI and $p$-QDO.

The study of physical and mechanical characteristics of the obtained composites shows that the presence of active functional groups in the original materials helps to improve their strength characteristics. The results of physico-mechanical studies of the obtained materials are shown in Fig. 4.

The obtained data of the influence of modifying of blocked MDI on $\sigma_{p}$ and $\Delta \varepsilon$ of the compositions indicate that the properties of the polymer compositions depend on the ratio between PEVA, CR and the modifier. The maximum of $\sigma_{p}$ is observed when the content of the blocked MDI is $3 \mathrm{wt} \%$, that is by $62 \%$ higher than the $\sigma_{p}$ value of the control sample without a modifier. A maximum of $\Delta \varepsilon$ is achieved at blocked MDI content of 15 wt $\%$, which is $234 \%$ higher the $\Delta \varepsilon$ value of the unmodified rubber plastics.

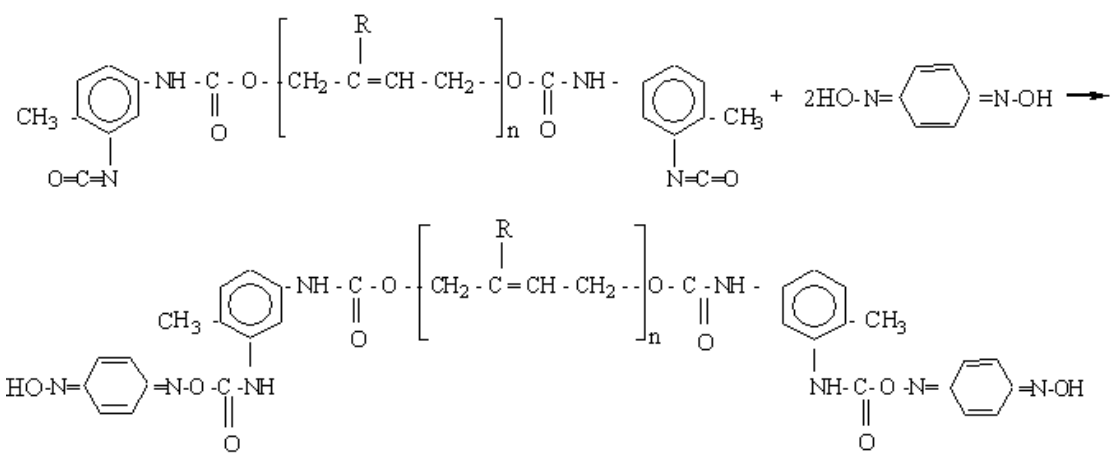

Scheme 2
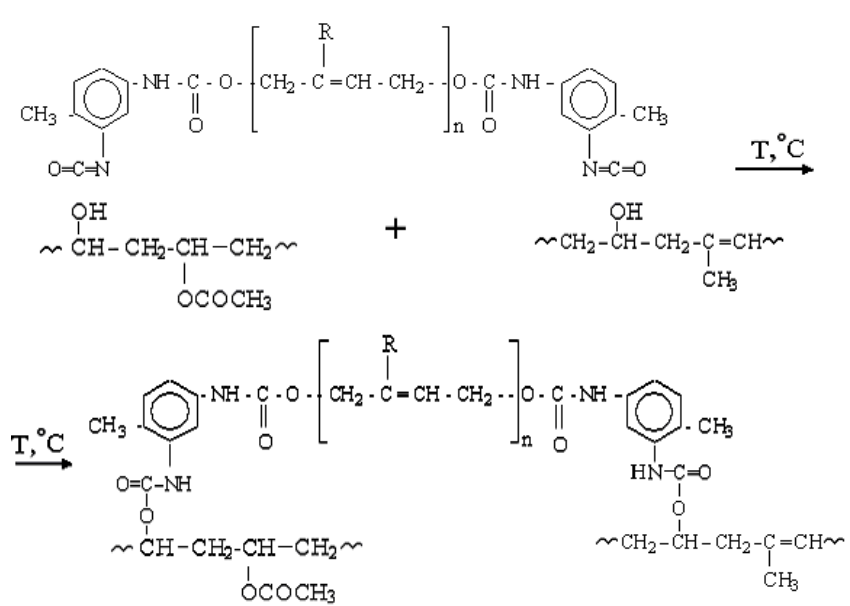

Scheme 3 

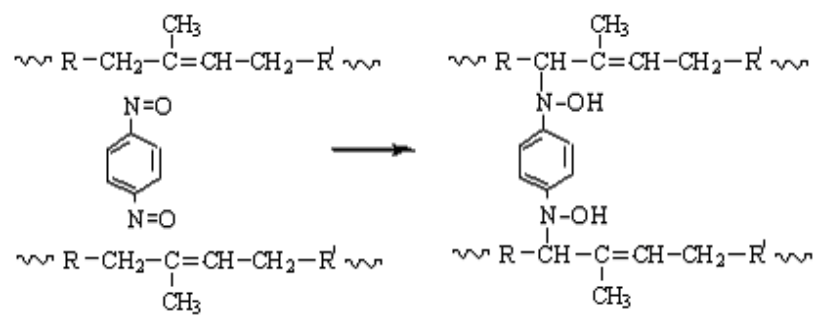

Scheme 4

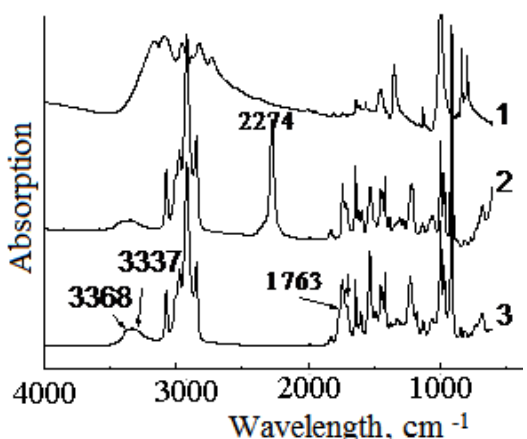

Fig. 3. FTIR spectra: $p$-QDO (1); MDI (2) and blocked MDI (3)

\section{Conclusions}

Thus, studies show the efficiency of blocked MDI modifying action for the composites based on functionalized PEVA 3345 and CR. Addition of modifier improves the mechanical and deformation characteristics of the composites. Introduction of blocked MDI to the mixture consisting of 50\% RC and 50\% PEVA with hydroxyl groups, leads to the increase of tensile strength and relative elongation by 1.6-2.3 times, which may be due to the structural and chemical processes, as well as interactions between reactive groups on the surface of the crumbs and PEVA. So, application of blocked MDI as a modifier for rubber plastics materials gives the ability to create thermoplastic composites with high mechanical performance.

\section{References}

[1] Tutorsky I., Potapov E., Schwartz A.: Khimicheskaya Modifikacia Elastomeriv. Khimiya, Moskva 1993.

[2] Guicun Q., Xiaohong Z., Binghai L. et al.: Polym. Chem., 2011, 2 1271. https://doi.org/10.1039/c0py00413h

[3] Kostromina N., Borisov S., Ivashkina V. and Osipchyk V.: Adv. Chem. Chem. Technol., 2014, 28, 152.

[4] Changqing F., Xiaoting Q., Ruien Y. et al.: J. Appl. Polym. Sci., 2016, 27, 133.

[5] Serenko O., Goncharuk G., Meshkov B. et al.: Polym. Sci., 2016, 48, 64.

[6] Kujat C.: Pat. EP 2868453 A1. Publ. May 06, 2015.

[7] Wenxian Z., Zhenping S., Liangliang S. et al.: Acad. J. Key Eng. Mat., 2016, 680, 451.

https://doi.org/10.4028/www.scientific.net/KEM.680.451

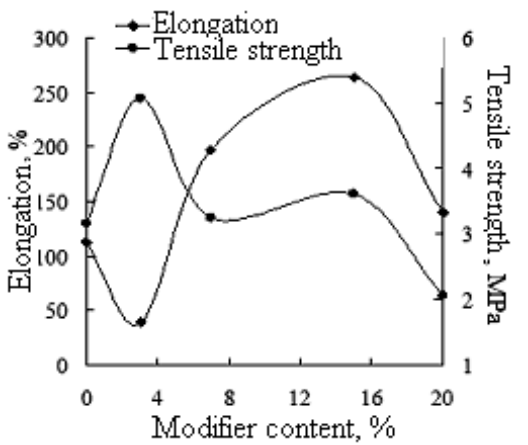

Fig. 4. The dependence of the tensile strength and elongation at break of rubber plastics from the content of the blocked MDI

[8] Koning C., Van Duin M.: Progr. Polym. Sci., 1998, 23, 707. https://doi.org/10.1016/S0079-6700(97)00054-3

[9] Klotz S., Cantow H.-J.: Polymer, 1990, 2, 315.

https://doi.org/10.1016/0032-3861(90)90125-I

[10] Myshak V., Grishchenko V., Seminog V. et al.: Voprosy Khim. i Khim. Techn., 2013, 5, 38.

[11] Mogilevich G., Turov B., Morozov Ye. et al.: Zhydkie Uglevodorodnye Kauchuki, Khimiya, Moskva 1983.

[12] Myshak V., Lebedev Ye., Barantsova A. et al. Polymer. Zh., 2006, 3, 246.

[13] Kuptsov A., Zhizhin G.: Fourier-Spectry Kombinatsionnogo Rasseyaniya i Infrakrasnogo Pogloshcheniya Polymerov. Fizmatlit, Moskva 2001.

Received: October 26, 2016 / Revised: November 10, 2016 / Accepted: J anuary 21, 2017

\section{МОДИФІКОВАНІ КОМПОЗИТИ НА ОСНОВІ КОПОЛІМЕРІВ ЕТИЛЕНУ 3 ВІНІЛАЦЕТАТОМ ТА ГУМОВОЇ КРИХТИ}

Анотація. Синтезовано блокований макродіізочіанат (МДI) на основі гідроксилвмісного олігодієну та блокуючого агенту - n-хінондіоксиму. Досліджено вплив модифікатору блокованого МДІ, на фізико-механічні характеристики та структурні особливості композииійних матеріалів, отриманих на основі дисперсної гумової крихти та гідроксилвмісного кополімеру етилену з вінілацетатом. Визначено ефективні кониентраиії блокованого МДІ та його вплив на механічні та деформаційні характеристикиі полімерних композиційних матеріалів. Показано, щзо використання блокованого МДІ як модифікатора вище зазначених композитів приводить до покращення їх міџнісних характеристик.

Ключові слова: гумова крихта, кополімер етилену 3 вінілацетатом, блокований макродіізоиіанат, композиційні матеріали, модифікація. 